\title{
Laser Radiation Induces Growth and Lipid Accumulation in the Seawater Microalga Chlorella pacifica
}

\author{
Haonan Zhang ${ }^{\dagger}$, Zhengquan Gao ${ }^{\dagger, *}$, Zhe Li, Huanmin Du, Bin Lin, Meng Cui, Yonghao Yin, \\ Fengming Lei, Chunyu Yu and Chunxiao Meng* \\ School of Life Sciences, Shandong University of Technology, Zibo 255049, China; \\ zhanghaonan941018@163.com (H.Z.); m13789861521@163.com (Z.L.); 18369909105@163.com (H.D.); \\ 18369909032@163.com (B.L.); m17865918927@163.com (M.C.); 17865912602@163.com (Y.Y.); \\ hongyexinjian@163.com (F.L.); yuchunyu@yeah.net (C.Y.) \\ * Correspondence: zq7723@126.com (Z.G.); mengchunxiao@126.com (C.M.); Tel.: +86-533-2781329 (Z.G. \& C.M.) \\ + These authors equally contributed to this work.
}

Academic Editor: Paul L. Chen

Received: 13 September 2017; Accepted: 16 October 2017; Published: 22 October 2017

\begin{abstract}
The impacts of laser radiation (Nd: YAG laser, $1064 \mathrm{~nm}$ at $800 \mathrm{~mW}$, He-Ne laser $808 \mathrm{~nm}$ at $6 \mathrm{~W}$, semiconductor laser $632.8 \mathrm{~nm}$ at $40 \mathrm{~mW}$ ) on growth and lipid accumulation of Chlorella pacifica were investigated in this study. The results showed growth rates increased 1.23, 1.41, and 1.40-fold over controls by $4 \mathrm{~min} \mathrm{Nd:} \mathrm{YAG,} 4 \mathrm{~min} \mathrm{He}-\mathrm{Ne}$, and $8 \mathrm{~min}$ semiconductor laser treatments, respectively, whereas the corresponding nitrate reductase observed increased 1.25, 1.63, and 2.08-fold over controls. Moreover, total chlorophyll concentration was increased to 1.09, 1.29, and 1.33-fold over controls, respectively. After 20 days cultivation, the highest lipid content was $35.99 \%, 18.46 \%$, and $31.00 \%$ after 2 min Nd: YAG, 4 min He-Ne, and 4 min semiconductor laser treatments, corresponding to 2.86, 1.50, and 2.46-fold increase over controls, respectively. Furthermore, the lipid productivity of the above 3 treatments were $15.25 \pm 2.56,16.25 \pm 2.45$, and $14.75 \pm 2.11 \mathrm{mg} \mathrm{L}^{-1} \mathrm{~d}^{-1}$. However, the highest lipid productivity was $22.00 \pm 3.28,16.25 \pm 2.45$, and $19.25 \pm 1.78 \mathrm{mg} \mathrm{L}^{-1} \mathrm{~d}^{-1}$, in response to treatment for $2 \mathrm{~min} \mathrm{Nd:} \mathrm{YAG,} 1 \mathrm{~min} \mathrm{He}-\mathrm{Ne}$, and $4 \mathrm{~min}$ semiconductor laser treatments, with 2.67, 1.97, and 2.33-fold increase over controls, respectively. These results indicated that lipid accumulation efficiency of $C$. pacifica could be significantly improved by laser irradiation using $\mathrm{Nd}$ : YAG, He-Ne, and semiconductor laser treatments.
\end{abstract}

Keywords: cell growth; Chlorella pacifica; chlorophylls; laser irradiation; lipid productivity; nitrate reductase

\section{Introduction}

There is an urgent need for renewable energy sources that do not cause significant environmental harm and do not compete with food supply. Due to higher biomass production and faster growth, microalgae have been receiving attention as potential candidates for biodiesel production [1]. The production of biodiesel from microalgae has received much attention in recent years [2]. Huang et al. provided an overview of the advances and prospects of biodiesel production from microalgae [3]. Microalgae can transform carbon dioxide from the air and light energy through photosynthesis to various forms of chemical energy such as polysaccharides, proteins, lipids, and hydrocarbons [2]. As a result, microalgae have been studied as alternative feedstock for biodiesel production [1]. Microalgal biodiesel is environmentally advantageous in that it is a carbon neutral fuel due to the photosynthetic fixation of atmospheric carbon dioxide having properties similar to those of petrodiesel [4]. The lipids 
from microalgae could be used as a transformation to biofuel, especially biodiesel. Previous studies have demonstrated that lipid content in some microalgae could be increased by various cultivation conditions [2,4]. Algae, as a source of biofuel, offer many advantages over traditional biofuel crops. These advantages include the potential to be grown on marginal land, the use of water sources not suitable for agriculture (e.g., high salt content could be tolerated), high growth rates, and relatively high lipid content [5]. Many microalgae strains have naturally high lipid content (ca. 20-50\% dry weight) under nitrogen limitation [6-10], high light [11,12], temperature [7,13], salinity [14], and pH [15].

Microalgae contain a diverse composition of lipids, which are vital to cell growth and metabolic activities [16]. Microalgae lipids are one of the most valuable components of microalgae biomass for biofuel production [16]. Moreover, much more valuable products such as fine chemicals and bioactive compounds, food source and feed additive, and so forth, can be recovered from microalgae. Furthermore, when combined with processes such as wastewater and flue gas treatments, microalgae biodiesel and other bio-products are more environmentally sustainable, cost-effective, and profitable [17]. However, lipid accumulation generally has an antagonistic relationship to growth rate and the low lipid content or low biomass will inevitably raise the cost of biodiesel from microalgae posing a hindrance to industrial production [2]. Therefore, isolation of microalgae with a higher lipid content suited for large scale production is a vital step for biodiesel production [17]. Neenan et al., in a report prepared for the U.S. Department of Energy, stated that the ability to produce lipids that can constitute $60 \%$ or more of the total biomass is a distinguishing characteristic of microalgae, making them a uniquely attractive candidate for conversion to liquid fuel [18].

Even with assumptions about biological productivity, Sheehan et al. projected costs for biodiesel, which were two times higher than current petroleum diesel fuel costs [19]. Even though many advances have been made in the last two decades, microalgae biodiesel has not been produced commercially until recently. The reasons for the delay in production, including factors that most influence cost, are biological and not engineering-related [20]. These analyses point to the need for highly productive organisms that are capable of near-theoretical levels of conversion of sunlight to biomass. What is needed information on intrinsic properties of selected algae strains through species screening as well as research on culture conditions and effective production systems [3].

Both the quantity and the quality of lipid production vary with the algal species that are present in the water, as well as with site-specific growth conditions [21]. Among the factors that induce microalgae to accumulate lipid, light is known to have an obvious influence on the lipid accumulation in various species. In addition, light is easy to control and is inexpensive when compared with other factors. Therefore, it is feasible to enhance the lipid content by light using laser radiation. Moreover, laser radiation could be used widely in agriculture and microbial breeding as a biostimulator device [22]. It also can be a candidate for microalgae mutation breeding.

Nitrate reductase (NR) is a key enzyme in nitrogen assimilation, and it catalyzes the nitrate-to-nitrite reduction process in plants [23]. NR catalyzes the first step of the denitrification pathway, where nitrate $\left(\mathrm{NO}^{3-}\right)$ is reduced to nitrite $\left(\mathrm{NO}^{2-}\right)$ [24]. To date, there is no experimental evidence that relates NR with lipid accumulation under laser stress. To better understand the effects of several kinds of lasers on cell growth and lipid accumulation, it is necessary to elucidate the interactions between lipid accumulation, cell growth, and laser irradiation. In this work, Chlorella pacifica was used and preliminary results were obtained here by determination of cell growth, lipid content, and NR levels associated with lipid metabolism after treated by three types of lasers (Nd: YAG, He-Ne, and semiconductor).

\section{Results}

\subsection{Cell Growth Assay}

The standard curves between cell density $\left(\times 10^{6}\right.$ cells $\left.\mathrm{mL}^{-1}\right)$ and $\mathrm{OD}_{540 \mathrm{~nm}}$, as well as growth curves of $C$. pacifica with different laser sources are shown in Figure 1 The regression equation was 
$y=10.954 x+0.1679$ and $R^{2}$ was 0.997 , which represented the calibration curve between $O_{540 \mathrm{~nm}}$ and cell number. Figures $2-4$ show the cell growth curve of $C$. pacifica after treatment with the three types of lasers. After 20 days of cultivation under normal conditions, as compared to the controls, maximum cell growth was observed at $4 \mathrm{~min}$ irradiation with the He-Ne laser, followed by 8 min irradiation with the semiconductor laser, and lastly $4 \mathrm{~min}$ irradiation with the Nd: YAG laser with values of 1.41, 1.40, and 1.23-fold over controls, respectively. Moreover, there were higher growth rates observed with $16 \mathrm{~min}$ of Nd: YAG radiation treatment, at 1, 8, and $16 \mathrm{~min}$ of He-Ne radiation, and at 1, 2, 4, 12, and $16 \mathrm{~min}$ of semiconductor radiation, respectively.

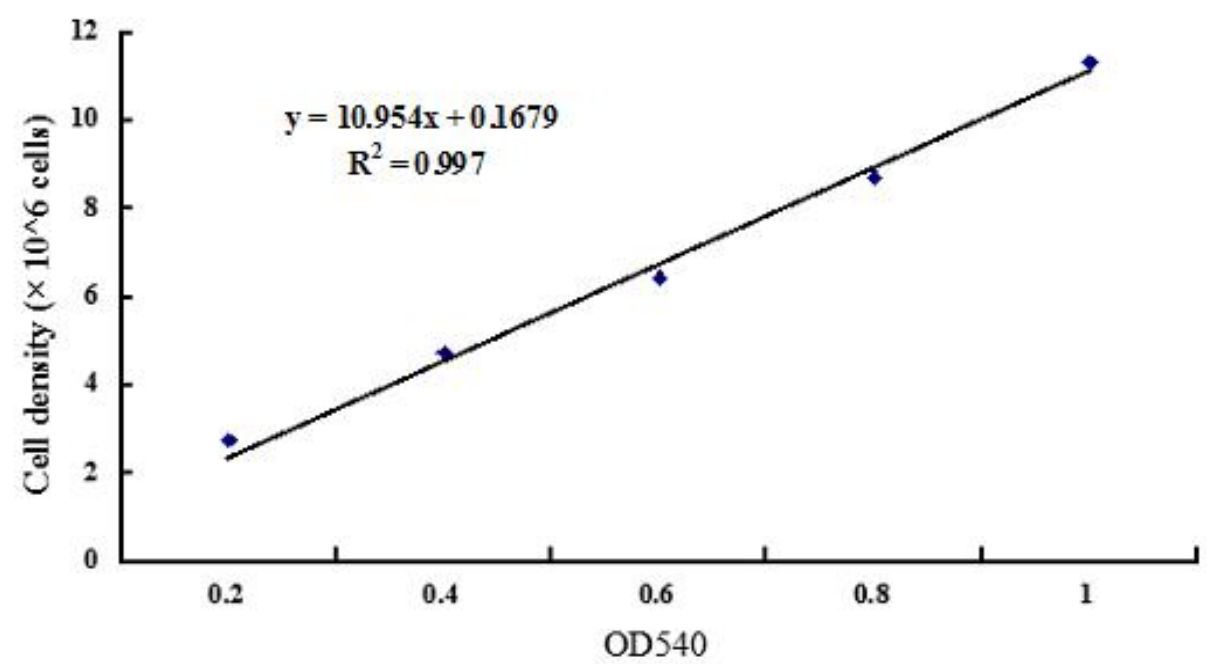

Figure 1. The calibration curve between OD540 and cell density.

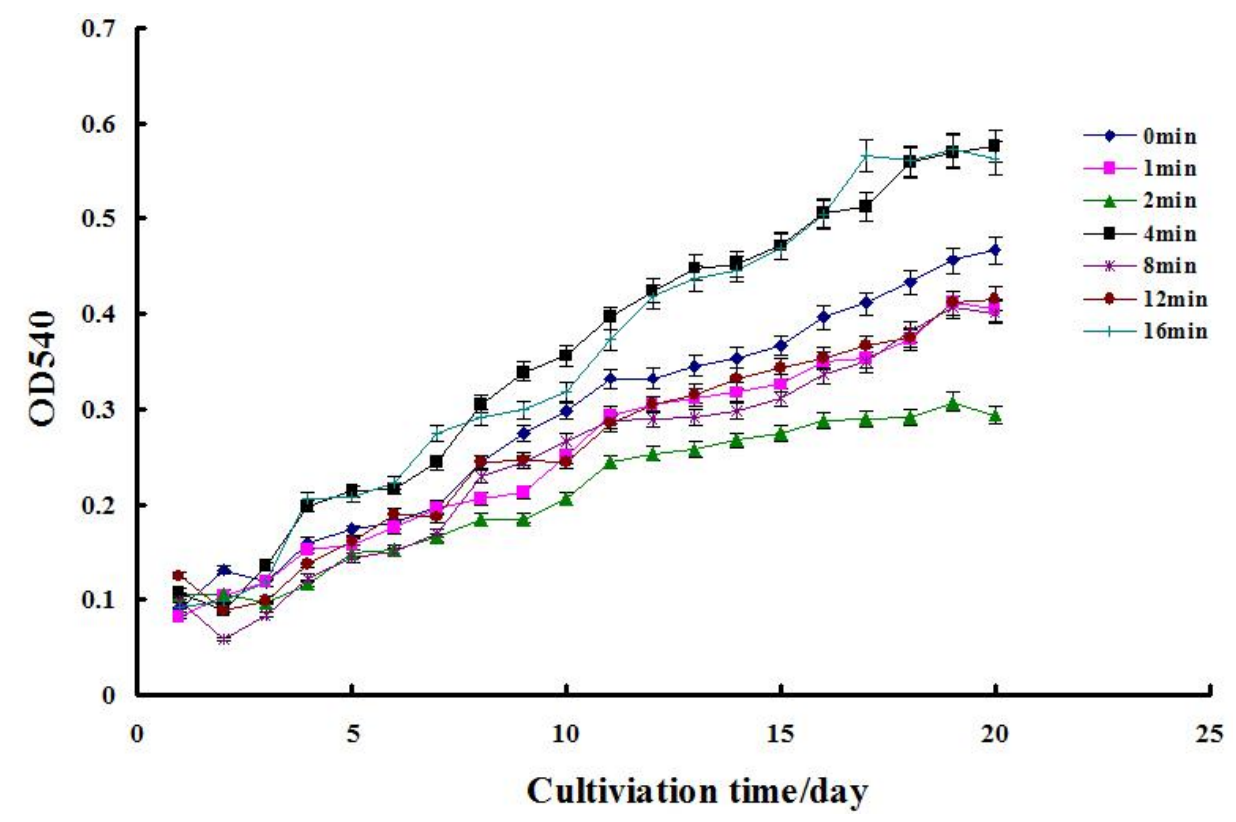

Figure 2. Microalgal cell growth curves after irradiated by Nd: YAG Laser with different time. 


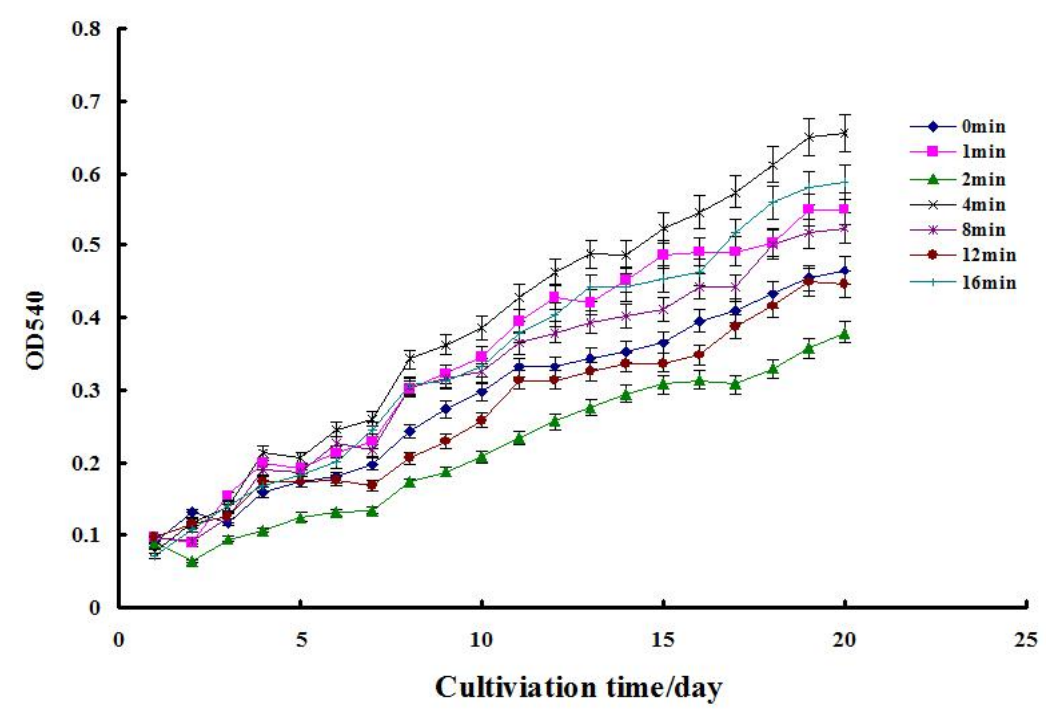

Figure 3. Microalgal cell growth curves after irradiated by He-Ne Laser with different time.

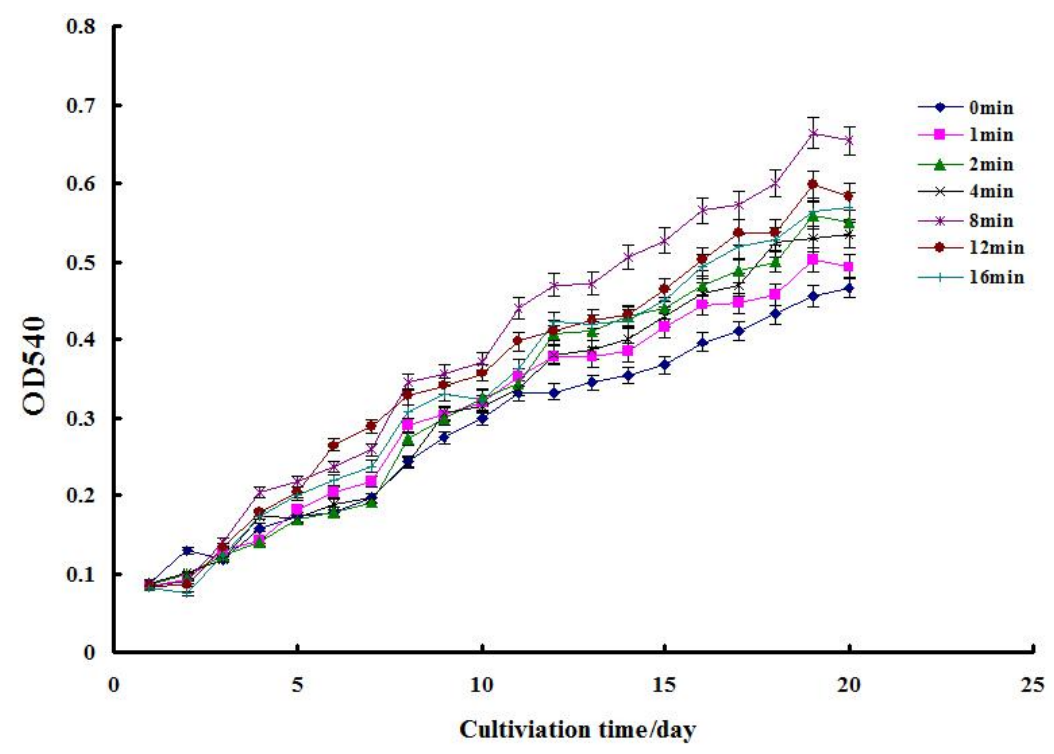

Figure 4. Microalgal cell growth curves after irradiated by semiconductor Laser with different time.

\subsection{Measurement of Total Chlorophyll}

Figure 5 shows the total chlorophyll concentration of $C$. pacifica after irradiation by the three types of lasers. After 20 days of cultivation under normal conditions, the maximum total chlorophyll concentration was observed to be $3.35,3.96$, and $4.11 \mu \mathrm{g} \cdot \mathrm{mL}^{-1}$ at $4 \mathrm{~min}$ irradiation with the Nd: YAG laser, 4 min irradiation with the He-Ne laser, and $8 \mathrm{~min}$ irradiation with the semiconductor laser, respectively. These results were 1.09, 1.29, and 1.33-fold over controls, respectively. Moreover, when compared to the controls, there were higher chlorophyll concentrations after $16 \mathrm{~min}$ of Nd: YAG irradiation, after 1, 8, and $16 \mathrm{~min}$ of He-Ne irradiation and after 2, 4, 8, and $12 \mathrm{~min}$ of semiconductor irradiation, respectively. 


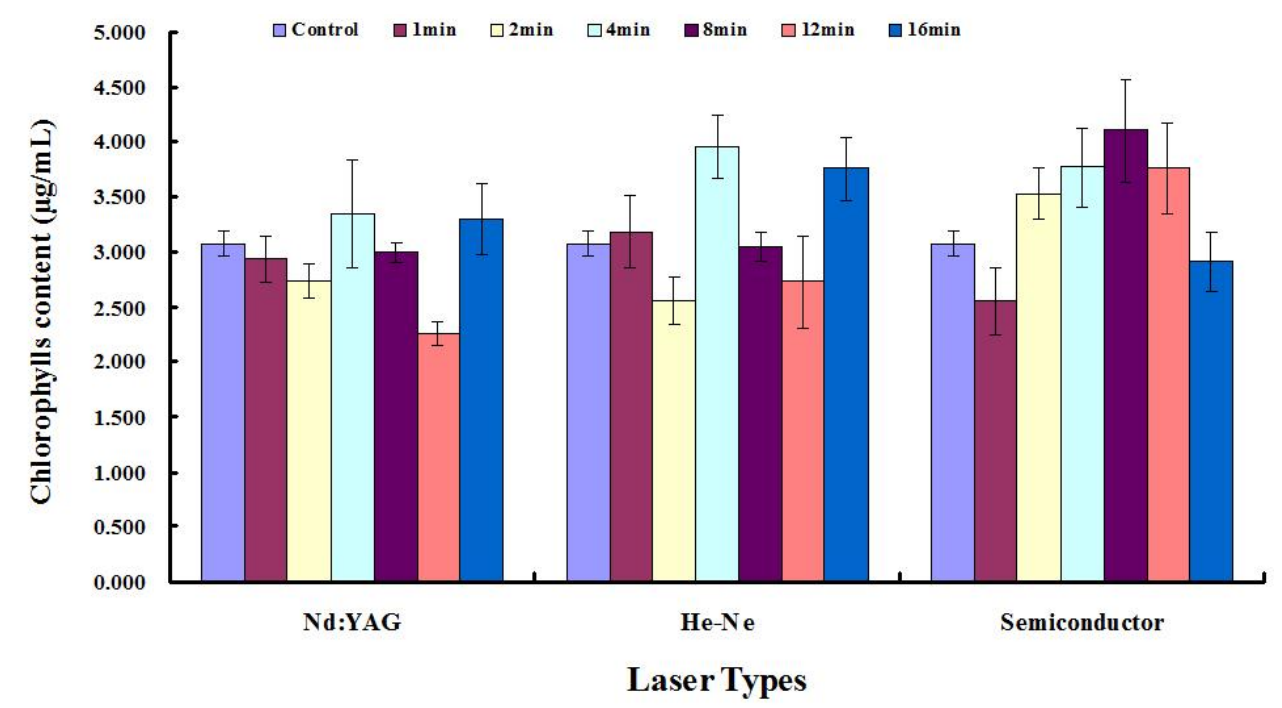

Figure 5. Total microalgal chlorophyll content after irradiated for different time by three lasers.

\subsection{Nitrate Reductase Levels}

Figure 6 shows the NR activity of $C$. pacifica samples irradiated with the three types of lasers. The maximum NR activity was observed at $27.39,35.72$, and $45.53 \mu \mathrm{g} \cdot \mathrm{g}^{-1} \cdot \mathrm{h}^{-1}$ after a $4 \mathrm{~min}$ treatment with the Nd: YAG laser, a 4 min treatment with the He-Ne laser, and an 8 min treatment with the semiconductor laser, representing 1.25, 1.63, and 2.08-fold control preparations, respectively. Moreover, as compared to the controls, there were higher NR levels after a 1 min treatment with the Nd: YAG laser, after 1, 12, and 16 min treatments with the He-Ne laser, and after a 4 min treatment with the semiconductor laser, respectively.

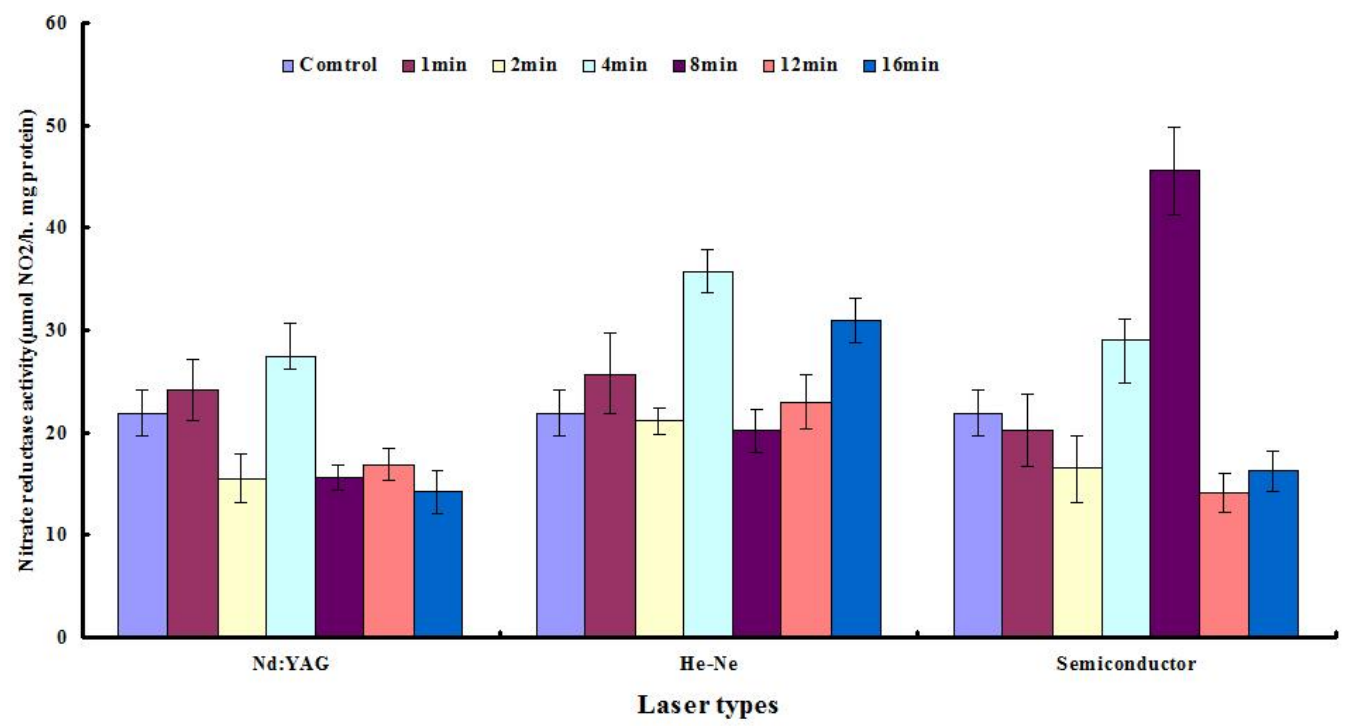

Figure 6. The nitrate reductase activity of microalgae sample after irradiated for different time by three type of lasers.

\subsection{Microscopic Analyses}

Figure 7 shows fluorescence and light microscopy images, of $C$. pacifica after laser radiation. Figure $7 \mathrm{a}, \mathrm{b}$ show optical microscopic images and fluorescence images of control preparations dyed with Nile red. Figure 7c,d represent optical microscopic images and fluorescence images of samples treated 
with the He-Ne laser for $4 \mathrm{~min}$. Figure 7e,f represent optical microscopic images and fluorescence images of samples treated with the semiconductor laser for $4 \mathrm{~min}$. Figure $7 \mathrm{~g}$,h represent optical microscopic images and fluorescence images of samples treated with the Nd: YAG laser for $2 \mathrm{~min}$.
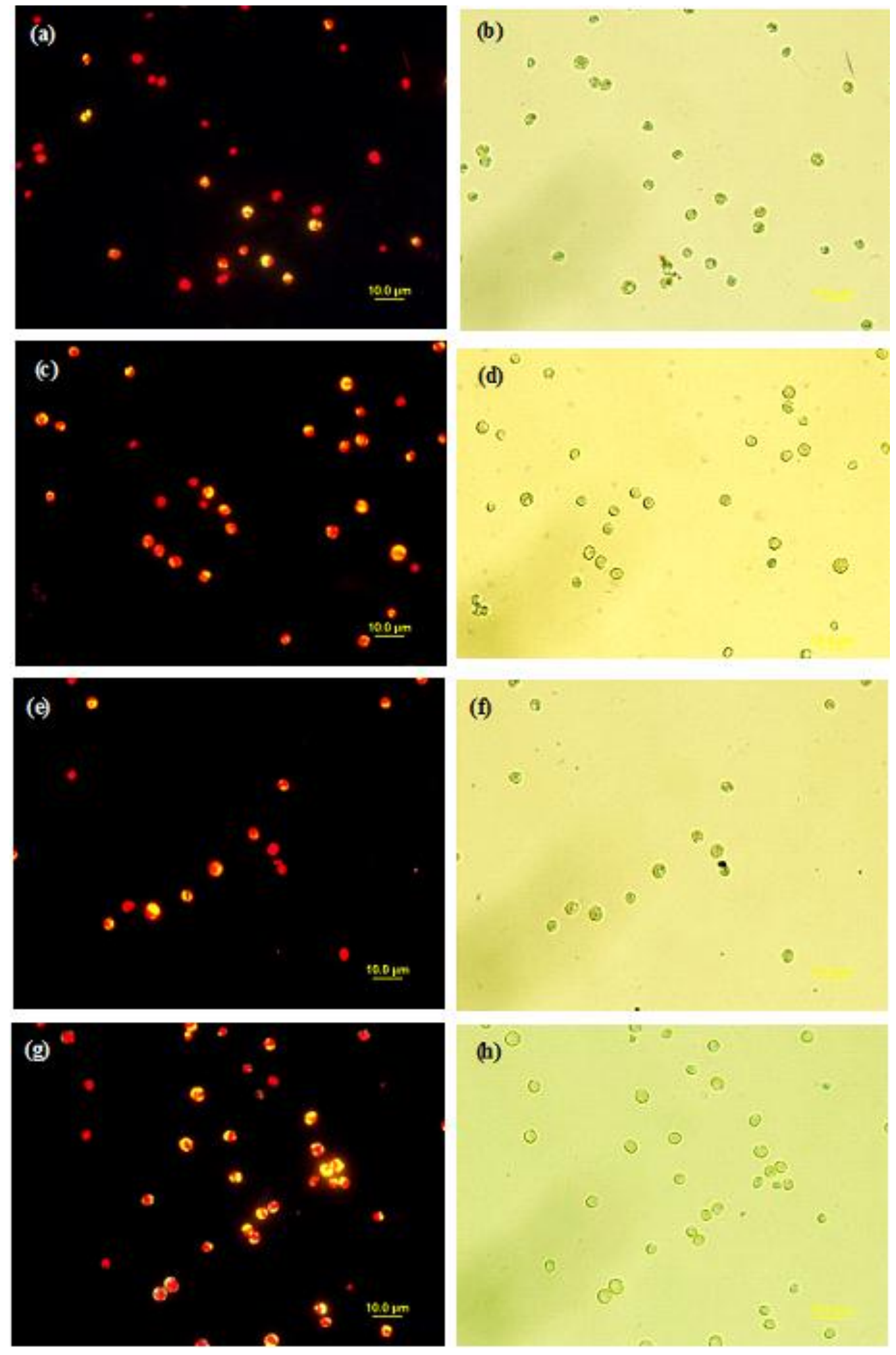

Figure 7. Fluorescence (a,c,e,g) and light microscopy (b,d,f,h) images of C. pacifica after laser radiation. Bar $=10 \mu \mathrm{m}$. 
Visible orange fluorescence was observed in both the controls and samples treated with the three types of lasers, suggesting neutral lipid accumulation. However, the least fluorescence sensitivity was observed in the control group, followed by samples treated with the He-Ne radiation for $4 \mathrm{~min}$, then the greater fluorescence in samples treated with the semiconductor radiation for $4 \mathrm{~min}$, followed by the greatest intensity observed in samples treated with Nd: YAG radiation for $2 \mathrm{~min}$. Thus, the data suggest that the highest lipid accumulation resulted from the Nd: YAG radiation for $2 \mathrm{~min}$.

\subsection{Determination of Lipid Content}

Figure 8 shows changes in total lipid contents $(\%, w / w)$ after 20 days of normal C. pacifica cultivation, treated with the three types of lasers. Compared to that of the controls (12.58\%), the highest lipid content was observed as $35.99 \%, 18.46 \%$, and $31 \%$, after treatment with the Nd: YAG laser, the He-Ne laser and the semiconductor laser for 2, 4 and $4 \mathrm{~min}$, respectively. This represented 2.86, 1.50, and 2.46-fold increase over controls. Moreover, there were higher lipid contents at 1, 4, 12 and $16 \mathrm{~min}$ after Nd: YAG radiation, 1, 2, 8, 12 and $16 \mathrm{~min}$ after He-Ne radiation and 8 and $12 \mathrm{~min}$ after semiconductor radiation, respectively. These results, derived from cell growth and lipid accumulation, showed that the selection of algal strains with favorable growth rates and lipid content might be $4 \mathrm{~min}$ treatment with He-Ne laser and the 4 min treatment with the semiconductor radiation for optimum cultivation. However, the peak of lipid content (35.99\%) observed at 2 min after Nd: YAG irradiation corresponded to lower cell growth in C. pacifica.

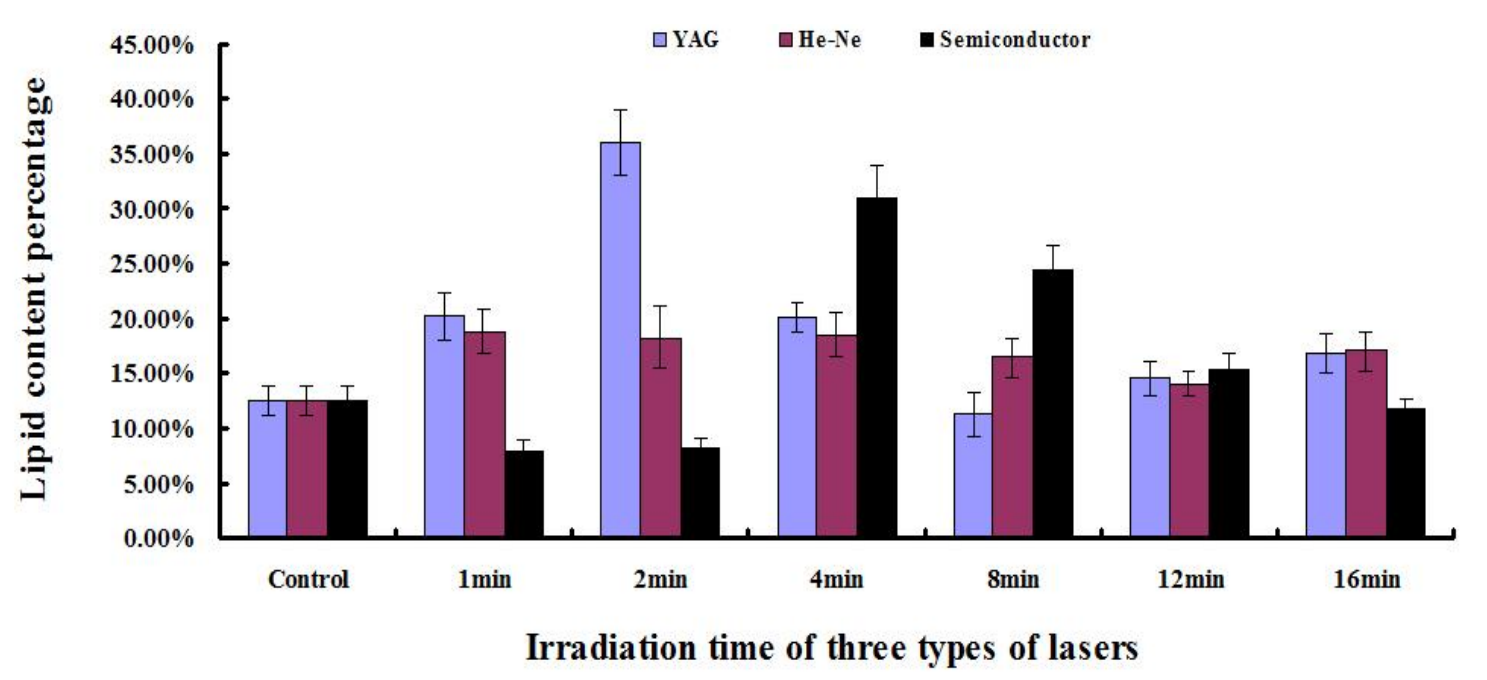

Figure 8. Total microalgal lipid content after irradiated for different time by three lasers.

\subsection{Lipid Productivity}

Tables 1-3 show the total biomass dry weight and total lipid content between control preparations and laser radiation treatments. In the Nd: YAG laser treatment group, the biomass of algal samples significantly increased, with the exception of the 2 min treatment, which showed a modest decrease compared to that of the controls. All of the treatments of Nd: YAG radiation showed an increase in both total lipids and lipid productivity compared to the controls. Moreover, five treatments $(1,2,4,8$, $16 \mathrm{~min}$ ) led to higher lipid productivity, in which the $2 \mathrm{~min}$ treatment induced 2.67-fold over controls at $22.00 \pm 3.28 \mathrm{mg} \mathrm{L}^{-1} \mathrm{~d}^{-1}$. In the He-Ne laser treatment groups, only 1, 4, 8, and 16 min treatments resulted in an increase in biomass over the controls, whereas the other treatments had little effect on the biomass. Specifically, all except the 16 min treatment had higher lipid content when compared to the controls, with a 1.49-fold increase over controls in the 1 min treatment. Similar results regarding lipid productivity were observed in the 1,2, 4, 12 min treatment groups with a 1.97-fold increase in the 4 min treatment, as compared to controls. 
Table 1. Biomass concentrations, total lipid content and lipid productivity of C. pacifica treated by Nd: YAG laser gradients at the end of cultiviation.

\begin{tabular}{cccc}
\hline Treatments of Nd: YAG Laser & Biomass $\mathbf{~ L ~ L}^{\mathbf{- 1}}$ & Total Lipid $\mathbf{g ~ L}^{-\mathbf{1}}$ & Lipid Productivity $\mathbf{~ m g ~ L ~}^{\mathbf{- 1}} \mathbf{d}^{\mathbf{- 1}}$ \\
\hline Control & $0.258 \pm 0.017$ & $0.033 \pm 0.003$ & $8.254 \pm 1.662$ \\
$1 \mathrm{~min}$ & $0.322 \pm 0.025^{*}$ & $0.064 \pm 0.006^{* *}$ & $16.004 \pm 2.313^{* *}$ \\
$2 \mathrm{~min}$ & $0.251 \pm 0.019$ & $0.088 \pm 0.008^{* *}$ & $22.001 \pm 3.278^{* *}$ \\
$4 \mathrm{~min}$ & $0.417 \pm 0.028^{* *}$ & $0.061 \pm 0.004^{* *}$ & $15.246 \pm 2.557^{* *}$ \\
$8 \mathrm{~min}$ & $0.303 \pm 0.023$ & $0.048 \pm 0.004^{*}$ & $11.995 \pm 1.382^{* *}$ \\
$12 \mathrm{~min}$ & $0.289 \pm 0.021$ & $0.042 \pm 0.003^{*}$ & $10.497 \pm 1.104$ \\
$16 \mathrm{~min}$ & $0.329 \pm 0.021^{*}$ & $0.055 \pm 0.051^{*}$ & $13.753 \pm 1.652^{* *}$ \\
\hline
\end{tabular}

Table 2. Biomass concentrations, total lipid content, and lipid productivity of C. pacifica treated by He-Ne laser.

\begin{tabular}{cccc}
\hline Treatments of He-Ne Laser & Biomass $\mathbf{~ L ~}^{\mathbf{- 1}}$ & Total Lipid $\mathbf{g ~ L}^{-\mathbf{1}}$ & Lipid Productivity $\mathbf{~ g L ~}^{-\mathbf{1}} \mathbf{d}^{-\mathbf{1}}$ \\
\hline Control & $0.258 \pm 0.017$ & $0.033 \pm 0.003$ & $8.254 \pm 1.662$ \\
$1 \mathrm{~min}$ & $0.341 \pm 0.028^{*}$ & $0.056 \pm 0.003^{*}$ & $14.002 \pm 1.274^{*}$ \\
$2 \mathrm{~min}$ & $0.214 \pm 0.021^{*}$ & $0.046 \pm 0.0065^{* *}$ & $11.493 \pm 1.531^{* *}$ \\
$4 \mathrm{~min}$ & $0.449 \pm 0.020^{* *}$ & $0.065 \pm 0.007^{* *}$ & $16.254 \pm 2.452^{* *}$ \\
$8 \mathrm{~min}$ & $0.317 \pm 0.035$ & $0.035 \pm 0.003$ & $8.746 \pm 1.512$ \\
$12 \mathrm{~min}$ & $0.242 \pm 0.031^{*}$ & $0.045 \pm 0.006^{*}$ & $11.249 \pm 1.668^{*}$ \\
$16 \mathrm{~min}$ & $0.393 \pm 0.021^{* *}$ & $0.032 \pm 0.003$ & $8.004 \pm 1.032$ \\
\hline
\end{tabular}

Table 3. Biomass concentrations, total lipid content, and lipid productivity of C. pacifica treated by semiconductor laser.

\begin{tabular}{|c|c|c|c|}
\hline Treatments of Semiconductor Laser & Biomass $\mathrm{g} \mathrm{L}^{-1}$ & Total Lipid g $\mathrm{L}^{-1}$ & Lipid Productivity $\mathrm{mg} \mathrm{L}^{-1} \mathrm{~d}^{-1}$ \\
\hline Control & $0.258 \pm 0.017$ & $0.033 \pm 0.003$ & $8.254 \pm 1.662$ \\
\hline $1 \mathrm{~min}$ & $0.324 \pm 0.022 *$ & $0.026 \pm 0.003$ & $6.495 \pm 0.344$ \\
\hline $2 \mathrm{~min}$ & $0.435 \pm 0.028^{* *}$ & $0.364 \pm 0.003$ & $9.004 \pm 0.886$ \\
\hline $4 \mathrm{~min}$ & $0.354 \pm 0.031 *$ & $0.077 \pm 0.054^{* *}$ & $19.247 \pm 1.781 * *$ \\
\hline $8 \mathrm{~min}$ & $0.542 \pm 0.019 * *$ & $0.059 \pm 0.005^{* *}$ & $14.749 \pm 2.109 *$ \\
\hline $12 \mathrm{~min}$ & $0.423 \pm 0.029 * *$ & $0.043 \pm 0.005 *$ & $10.753 \pm 1.607$ \\
\hline $16 \mathrm{~min}$ & $0.449 \pm 0.002 * *$ & $0.028 \pm 0.003$ & $6.997 \pm 0.914$ \\
\hline
\end{tabular}

"(g. $\left.\mathrm{L}^{-1}\right)$ " represented the biomass weight or total lipid weight of $1 \mathrm{~L}$ microalgae culture. " $\mathrm{mg} \cdot \mathrm{L}^{-1} \cdot \mathrm{d}^{-1}$ " (per day) represented the average lipid productivity during 20 days of microalgae culture. "*" represented increased significantly ( $p$-value $<0.05$ ) and "**" increased different significantly ( $p$-value $<0.01)$, respectively.

In the semiconductor laser treatments, all the radiation gradients led to a significant increase in biomass. Four treatments $(2,4,8,12 \mathrm{~min})$ had higher lipid content, with a 2.33-fold increase in the 4 min treatment when compared to controls. Four treatments $(2,4,8,12 \mathrm{~min})$ had higher lipid productivity, but 1 and 16 min treatments showed less lipid productivity than the controls, with a 2.33-fold increase over of controls in the 4 min treatment.

\section{Discussion}

Laser mutation, as a new technique of breeding, has high energy density, comparative lower cost, operates at a single wave length, and has precise and efficient direction [25]. Laser radiation has a very high power density, so it has been used in accelerating seed germination and mutation breeding, and can be applied in new technical methods to improve the genes of trees and plants [26]. Ma et al. discussed the mechanism of the biological effects of lasers in accelerating seed germination, mutation breeding, and gene engineering of forest trees and horticultural plants [27]. Wang et al. demonstrated the effects of lasers on plant morphological, physiological, and genetic characteristics [28]. In this study, the effect of laser treatment on early embryological development of animals was examined in order to verify the theory and application of laser mutations in both plants and animals. 
Even though light is one important process parameter for microalgae cultivation, it is not fully optimized and little research is done regarding its spectral composition so far [29]. Recently, a few reports are available describing the effects of laser radiation on algae, or in microorganisms in general. Baer et al. certificated to investigate the right mixture of light for every microalgal strain and the desired product of interest individually is necessary [29]. de Mooij et al. found that the highest productivity was obtained using yellow light, while blue and red light resulted in the lowest light use efficiency under continuous illumination to Chlamydomonas reinhardtii [30]. Wang et al. revealed that Nd: YAG laser can be a hopeful mutagen method in Porphyridium cruentum breeding. They found irradiated cells grew rapidly in continue cultivation, growth increased 15.3-23.4\%; extracellular polysaccharides yield improved most, by $50.00-150.00 \%$ than control [31]. Nandakumar et al. [32] investigated the damage caused by pulsed laser irradiation from an Nd: YAG laser over varying time periods such as 2, 5, 10, 30, 60, and $300 \mathrm{~S}$ on two marine diatom species, namely Skeletonema costatum and Chaetoceros gracilis. Similarly, Enterobacter aerogenes W-23 bacteria was exposed to He-Ne laser irradiation to improve the hydrogen production ability [26]. Katsuda et al. found LED emitting light of short wavelengths $(380-470 \mathrm{~nm})$ induced astaxanthin accumulation of up to 5-6\% per dry-cell, although it caused the suppression of cell growth [33]. Kuwahara et al. reported that red and blue laser diodes were applied in growing the green algae Chlamydomonas reinhardtii to determine the effectiveness of laser diodes as an electric light source for algae production [34]. They found supplementing with either red with blue laser increased the algae cell count significantly, which exceeded the average by $241 \%$ than control under both red lasers and the white-light.

In the present study, three types of laser sources were used to examine cell growth of C. pacifica. The lasers used were the Nd: YAG laser, the He-Ne laser, and the semiconductor laser. After 20 days of cultivation under normal conditions, cell growth was determined after treatment with these laser sources. Moreover, $4 \mathrm{~min}$ and $16 \mathrm{~min}$ of irradiation with the Nd: YAG laser, $4 \mathrm{~min}$ and $16 \mathrm{~min}$ irradiation with the $\mathrm{He}-\mathrm{Ne}$ laser, as well as all treatments with the semiconductor laser could promote an increase of cell growth in C. pacifica. Further, 1, 2, 8, and 12 min of Nd: YAG laser treatment, and $2 \mathrm{~min}$ and $12 \mathrm{~min}$ of He-Ne treatment showed little effect on cell growth. There were almost the same change trends about the total chlorophyll amount as that of cell density. The highest total chlorophyll amount treatments in the treatments of three types lasers were $4 \mathrm{~min} \mathrm{Nd:} \mathrm{YAG} \mathrm{treatments}$ with 3.35, $4 \mathrm{~min} \mathrm{He}-\mathrm{Ne}$ treatments with $3.96 \mu \mathrm{g} \cdot \mathrm{mL}^{-1}$, and $8 \mathrm{~min}$ semiconductor treatments with $4.11 \mu \mathrm{g} \cdot \mathrm{mL}^{-1}$, respectively. The concentration was significantly higher than that of Chlorella vulgaris Beij. CCAP-211/11 $\mathrm{B}$ cultured with adding combined sodium selenite and metal ions in medium (highest content of $\mathrm{Chl}(\mathrm{a}+\mathrm{b})$ with $\left.0.73 \mu \mathrm{g} \cdot \mathrm{mL}^{-1}\right)$ [35]; but lower significantly than that of $C$. vulgaris cultured under different irradiance (37.50-100.00 $\mu \mathrm{mol}$ photons $\mathrm{m}^{-2} \cdot \mathrm{s}^{-1}$ ) and different photoperiods $\left(\mathrm{L} / \mathrm{D}=8: 16,12: 12,16: 8\right.$ ) (lowest content of $\mathrm{Chl}$ a with $7.40 \mu \mathrm{g} \cdot \mathrm{mL}^{-1}$ ) [36]. We speculated that it was the result of using different microalgae species, strains and different research methods. Therefore, continued research is necessary to select a suitable laser source and optimum time of radiation.

In this study, NR activity in C. pacifica was examined after irradiation with the three lasers. Lau et al. [37] reported immobilized C. vulgaris had the similar growth rate but half of NR activity of free cells with $300 \times 10^{6} \mu \mathrm{mol} \mathrm{NO} 2 \mu \mathrm{g} \cdot$ protein $^{-1} \cdot \mathrm{h}^{-1}$. Using a homogeneous laser source, different times of irradiation caused different effects on NR activities. The results presented here indicated that NR activity was increased in samples irradiated with the Nd: YAG laser (1 $\mathrm{min}, 4 \mathrm{~min}), \mathrm{He}-\mathrm{Ne}$ laser (1 $\mathrm{min}, 4 \mathrm{~min}, 16 \mathrm{~min}$ ), and the semiconductor laser (4 $\mathrm{min}, 8 \mathrm{~min}$ ).

Miao and $\mathrm{Wu}$ reported a heterotrophic growth of Chlorella protothecoides capable of yielding as high as $55.00 \%$ lipid content and converting the lipid to biodiesel [38]. Feng et al. reported that Chlorella vulgaris cultures achieved the highest lipid content (42.00\%) [1]. Tang et al. found lipid content was $35.3 \%$ before $\mathrm{N}$-depleted medium cultivation and up to $50 \%$ after $\mathrm{N}$-deprived medium cultivation in Chlorella minutissima [39]. Mehtani et al. reported mutants using ethyl methyl sulphonate (EMS) showed the maximum lipid content $(42 \%)$ as compared to wild type (27\%) with a 1.56-fold increase [40]. In the present study, it was found that laser irradiation played a crucial role in increasing lipid content 
and productivity within a cultivation period of 20 days. In our results, for the controls $(12.58 \%)$, the highest lipid content occurred in cells treated for $2 \mathrm{~min}$ by Nd: YAG, treated for 4 min by He-Ne, and treated by for $4 \mathrm{~min}$ semiconductor laser. Their lipid contents were $35.99 \%, 18.46 \%$, and $31.00 \%$, which was 2.86-, 1.50- and 2.46-fold of controls, respectively. The results above demonstrated laser possesses the considerable potential to mutate microalgae with higher lipid production like EMS.

Laser radiation on cell growth, lipid content, and productivity were also differential in the C. pacifica. Using the Nd: YAG laser irradiation, five treatments $(1,2,4,8,12 \mathrm{~min})$ led to higher lipid productivity and the highest one was $22.00 \pm 3.28 \mathrm{mg} \mathrm{L}^{-1} . \mathrm{d}^{-1}$ in the $2 \mathrm{~min}$ with 2.67 -fold of control. In the present study using the He-Ne laser, four treatments $(1,2,4,12 \mathrm{~min})$ had higher lipid productivity, with a 1.97 -fold increase in the 4 min treatment. Using the semiconductor laser, four treatments $(2,4,8,12 \mathrm{~min})$ had higher lipid productivity, with a 2.33-fold increase in the $4 \mathrm{~min}$ treatment. This leads to the question, why does laser radiation increase lipid content in these cells? Low power laser irradiation was demonstrated that it could activate the cellular metabolic vitality and promote increased functional activity [22]. One possiblity is that laser irradiation affects the lipid synthesis pathway and composition [41]. However, these possibilities require future studies and further experimentation. In this study, we explored the influence of laser treatment on the cell growth, lipid accumulation, and enzyme activities associated with lipid metabolism in C. pacifica. This work was a first attempt to increase the cell growth and lipid content in C. pacifica as a result of changes caused by laser irradiation. The cell growth, chlorophylls concentration, nitrate reductase, lipids content, and lipid productivity of C. pacifica had been analyzed to lay the foundation for microalgae breeding in biodiesel fuel production. Furthermore, additional research is needed to investigate the mechanisms modulating the lipid accumulation under laser stress.

Not all microalgae are amenable to direct engineering for biodiesel fuel production; rather, strains with the most desirable characteristics must be selected from thousands of natural species. Through breeding and molecular genetics, selected species can be altered to enhance these characteristics, and to suppress detrimental attributes. Thus, a primary task in mass culture development is the "engineering" of the organism itself.

\section{Materials and Methods}

\subsection{Algal Strain and Culture Medium}

C. pacifica 4\# [42] was obtained from the Microalgae Collection culture center (MACC) of the Ocean University of China, Qingdao. The cultures were unialgal and grown in sterilized artificial seawater enriched with F/2-Si medium containing $75 \mathrm{mg} \mathrm{NaNO} 3,5.65 \mathrm{mg} \mathrm{NaH}_{2} \mathrm{PO}_{4} \cdot 2 \mathrm{H}_{2} \mathrm{O}, 4.16 \mathrm{mg} \mathrm{Na}$ EDTA, $3.15 \mathrm{mg} \mathrm{FeCl} \cdot 6 \mathrm{H}_{2} \mathrm{O}, 0.01 \mathrm{mg} \mathrm{CuSO}{ }_{4} \cdot 5 \mathrm{H}_{2} \mathrm{O}, 0.022 \mathrm{mg} \mathrm{ZnSO} \cdot 7 \mathrm{H}_{2} \mathrm{O}, 0.01 \mathrm{mg} \mathrm{CoCl} 2 \cdot 6 \mathrm{H}_{2} \mathrm{O}, 0.18 \mathrm{mg}$ $\mathrm{MnCl}_{2} \cdot 4 \mathrm{H}_{2} \mathrm{O}, 0.006 \mathrm{mg} \mathrm{Na} 2 \mathrm{MoO}_{4} \cdot 2 \mathrm{H}_{2} \mathrm{O}, 0.0005 \mathrm{mg}$ vitamin $\mathrm{B}_{12}, 0.1 \mathrm{mg}$ vitamin $\mathrm{B}_{1}$, and $0.0005 \mathrm{mg}$ biotin per liter as described by Guillard and Ryther [43]. Cultures were incubated in $250 \mathrm{~mL}$ Erlenmeyer flasks at $25{ }^{\circ} \mathrm{C}$ with $36 \mu \mathrm{mol}$ photons $\mathrm{m}^{-2} \mathrm{~s}^{-1}$ light illumination and were hand shaken three to five times daily to avoid sticking.

\subsection{Laser Irradiation}

Twenty $\mathrm{mL}$ of algae samples in exponential growth phase were irradiated either by a Nd: YAG laser (WGL-3, GangDong, Tianjin, China), with a transition wavelength of $1064 \mathrm{~nm}$, a He-Ne laser (JD-2, Peiking University, Beijing, China), with a transition wavelength of $808 \mathrm{~nm}$ operating at $6 \mathrm{~W}$ for 1, 2, 4, 8, 12, and 16 min with pulse irradiation, or a semiconductor laser (LOS-BLD-0808-12W-C, Hite, Beijing, China), with a transition wavelength of $632.8 \mathrm{~nm}$ operating at $40 \mathrm{~mW}$ for 1, 2, 4, 8, 12, and $16 \mathrm{~min}$ with pulse irradiation, respectively. The diameter of treatment was $12 \mathrm{~mm}$ and the beam diameter was $100 \mu \mathrm{m}$. The algal samples were placed in the dark for $24 \mathrm{~h}$ and then were incubated at $25^{\circ} \mathrm{C}$ in $250 \mathrm{~mL}$ Erlenmeyer flasks with $\mathrm{F} / 2$ medium. The control samples were treated identically but not exposed to the laser irradiation. 


\subsection{Determination of Calibration Curves}

Calibration curves of $C$. pacifica were studied using a hemocytometer combined with optical density or absorption at $540 \mathrm{~nm}$. The steps were as follows: $10 \mathrm{~mL}$ aliquots of the algae solution were taken from treatment groups and $1 \mathrm{~mL}$ was put into the hemocytometer for counting cell number under the microscope. Then, $4 \mathrm{~mL}$ was used to measure absorbance at $540 \mathrm{~nm}\left(\mathrm{OD}_{540 \mathrm{~nm}}\right)$ [44]. The remaining $5 \mathrm{~mL}$ of the algae solution was diluted $2 \times$, and $1 \mathrm{~mL}$ was put into the hemocytometer for counting cell numbers under the microscope; $4 \mathrm{~mL}$ was used to measure $\mathrm{OD}_{540 \mathrm{~nm}}$. Similar experimental steps were executed 10 times and the calibration curve between $\mathrm{OD}_{540 \mathrm{~nm}}$ and cell density was drawn.

\subsection{The Quantification Of Total Chlorophyll Concentration}

Fresh algal solution was placed into $10 \mathrm{~mL}$ test tubes before centrifugation $\left(8000 \times g, 4{ }^{\circ} \mathrm{C}\right.$ for $10 \mathrm{~min}$ ). The pellet was collected, resuspended in $4 \mathrm{~mL}$ acetone, and placed into a $55^{\circ} \mathrm{C}$ water bath in the dark for $30 \mathrm{~min}$ before centrifugation $\left(8000 \times \mathrm{g}, 4^{\circ} \mathrm{C}\right.$ for $\left.10 \mathrm{~min}\right)$. The supernatant was collected and placed into a $10 \mathrm{~mL}$ volumetric flask. Chlorophyll content was determined colorimetrically [45].

\subsection{Determination of Nitrate Reductase Activity}

The nitrate reductase (NR) activity determination was made according to the method by Arrese-Igor et al. [46], as described by Jauregui et al. [47].

\subsection{Microscopic Analysis}

Microalgae cells were stained with $2 \mu \mathrm{g} \cdot \mathrm{mL}^{-1}$ Nile red (dissolved in acetone; Sigma, USA) for $15 \mathrm{~min}$ [48]. Observation of lipid bodies were conducted using a Nikon Eclipse 80i microscope (Nikon, Tokyo, Japan) and photographs were taken with a Nikon CCD DS-DP10 file digital camera (excitation: 510-550 nm, emission: $590 \mathrm{~nm}$ ).

\subsection{Measurements of Lipid Content with Gravimetric Methods}

Lipid percentage was calculated for each replicate. Algal cells were harvested by centrifugation at $8000 \times g, 4{ }^{\circ} \mathrm{C}$ for $10 \mathrm{~min}$ after 20 days of cultivation, then 4 days with nutrient starvation inducing lipid accumulation. After centrifugation at $8000 \times g, 4{ }^{\circ} \mathrm{C}$ for $10 \mathrm{~min}$, the supernatant was decanted and cell pellets were heat-dried in the oven at $100^{\circ} \mathrm{C}$ for $24 \mathrm{~h}$, then biomass was ground into a powder. The total lipid content was then extracted with chloroform/methanol and was quantified gravimetrically based on the method of Bligh and Dyer [49] with some modifications. A $100 \mathrm{mg}$ sample of dried microalgal powder was added to $4 \mathrm{~mL}$ methanol and $2 \mathrm{~mL}$ chloroform in a $50 \mathrm{~mL}$ test tube and mixed for $1 \mathrm{~min}$. Thereafter, the samples were disrupted by ultrasound and centrifuged at $8000 \times g, 4{ }^{\circ} \mathrm{C}$ for $10 \mathrm{~min}$. The upper layer was withdrawn using a pipette, and then $18 \mathrm{~mL}$ of chloroform and $18 \mathrm{~mL}$ of water were added and the solution and was mixed for $1 \mathrm{~min}$ in a $50 \mathrm{~mL}$ test tube. The lower chloroform phase containing the extracted lipids was transferred into a new tube and the algal pellets were re-extracted two more times until no color was visible in the extract. Finally, all of the chloroform phases were combined and evaporated in a nitrogen evaporator (QSC-12T, Quandao, Shanghai, China) until dry lipid was obtained. The lipid content was calculated as the percentage of algal dry weight.

\subsection{Statistical Analysis}

All reported data were the average value of the triplicates. Mean \pm SD data were statistically analyzed with one-way ANOVA. The LSD multiple comparisons test was used to determine the differences among groups of different trials. p-values of less than 0.05 were considered statistically significant. 
Acknowledgments: The present study was supported by Key Research and Development Program of Shandong Province (2016GSF121030, 2017GSF21105, 2017CXGC0309), the National Natural Science Foundation of China (31170279, 41106124), the Natural Science Foundation of Shandong province (ZR2011DM006, ZR2011CQ010), the Project of Shandong Province Higher Educational Science and Technology Program (J17KA132) and the Supporting Project for Young Teachers in Shandong University of Technology (4072-114021).

Author Contributions: Zhengquan Gao and Chunxiao Meng conceived and designed the experiments; Haonan Zhang, Huanmin Du, Zhe Li, Bin Lin, Fengming Lei performed the experiments; Meng Cui, Yonghao Yin, Chunyu Yu analyzed the data; Haonan Zhang, Huanmin Du and Bin Lin wrote the paper.

Conflicts of Interest: The authors declare no conflict of interest.

\section{References}

1. Feng, Y.J.; Li, C.; Zhang, D.W. Lipid production of Chlorella vulgaris cultured in artificial wastewater medium. Bioresour. Technol. 2011, 102, 101-105. [CrossRef] [PubMed]

2. Brennan, L.; Owende, P. Biofuels from microalgae-A review of technologies for production, processing, and extractions of biofuels and co-products. Renew. Sustain. Energy Rev. 2010, 14, 557-577. [CrossRef]

3. Huang, G.H.; Chen, F.; Wei, D.; Zhang, X.W.; Chen, G. Biodiesel production by microalgal biotechnology. Appl. Energy 2010, 87, 38-46. [CrossRef]

4. Ahmad, A.L.; Yasin, N.H.M.; Derek, C.J.C.; Lim, J.K. Microalgae as a sustainable energy source for biodiesel production: A review. Renew. Sustain. Energy Rev. 2011, 15, 584-593. [CrossRef]

5. Arenas, E.G.; Palacio, M.C.R.; Juantorena, A.U.; Fernando, S.E.L.; Sebastian, P.J. Microalgae as a potential source for biodiesel production: Techniques, methods, and other challenges. Int. J. Energy Res. 2017, 41, 761-789. [CrossRef]

6. Li, Y.Q.; Horsman, M.; Wang, B.; Wu, N.; Lan, C.Q. Effects of nitrogen sources on cell growth and lipid accumulation of green alga Neochloris oleoabundans. Appl. Microbiol. Biotechnol. 2008, 81, 629-636. [CrossRef] [PubMed]

7. Converti, A.; Casazza, A.A.; Ortiz, E.Y.; Perego, P.; Del Borghi, M. Effect of temperature and nitrogen concentration on the growth and lipid content of Nannochloropsis oculata and Chlorella vulgaris for biodiesel production. Chem. Eng. Process. Process Intensif. 2009, 48, 1146-1151. [CrossRef]

8. Hsieh, C.H.; Wu, W.T. Cultivation of microalgae for oil production with a cultivation strategy of urea limitation. Bioresour. Technol. 2009, 100, 3921-3926. [CrossRef] [PubMed]

9. Widjaja, A.; Chien, C.C.; Ju, Y.H. Study of increasing lipid production from fresh water microalgae Chlorella vulgaris. J. Taiwan Inst. Chem. Eng. 2009, 40, 13-20. [CrossRef]

10. Xin, L.; Hu, H.Y.; Ke, G.; Ying-Xue, S. Effects of different nitrogen and phosphorus concentrations on the growth, nutrient uptake, and lipid accumulation of a freshwater microalga Scenedesmus sp. Bioresour. Technol. 2010, 101, 5494-5500. [CrossRef] [PubMed]

11. Khotimchenko, S.V.; Yakovleva, I.M. Lipid composition of the red alga Tichocarpus crinitus exposed to different levels of photon irradiance. Phytochemistry 2005, 66, 73-79. [CrossRef] [PubMed]

12. Weldy, C.S.; Huesemann, M.H. Lipid production by Dunaliella salina in batch culture: Effects of nitrogen limitation and light intensity. J. Undergrad. Res. 2007, 7, 115-122.

13. Xin, L.; Hong-ying, H.; Yu-ping, Z. Growth and lipid accumulation properties of a freshwater microalga Scenedesmus sp. under different cultivation temperature. Bioresour. Technol. 2011, 102, 3098-3102.

14. Takagi, M.; Karseno; Yoshida, T. Effect of salt concentration on intracellular accumulation of lipids and triacylglyceride in marine microalgae Dunaliella cells. J. Biosci. Bioeng. 2006, 101, 223-226. [CrossRef] [PubMed]

15. Castrillo, M.; Lucas-Salas, L.M.; Rodríguez-Gil, C.; Martínez, D. High pH-induced flocculationsedimentation and effect of supernatant reuse on growth rate and lipid productivity of Scenedesmus obliquus and Chlorella vulgaris. Bioresour. Technol. 2013, 128, 324-329. [CrossRef] [PubMed]

16. Chia, M.A.; Lombardi, A.T.; Melão, M.G.G.; Parrish, C.C. Lipid composition of Chlorella vulgaris (Trebouxiophyceae) as a function of different cadmium and phosphate concentrations. Aquat. Toxicol. 2013, 128-129, 171-182. [CrossRef] [PubMed]

17. Mata, T.M.; Martins, A.A.; Caetano, N.S. Microalgae for biodiesel production and other applications: A review. Renew. Sustain. Energy Rev. 2010, 14, 217-232. [CrossRef] 
18. Neenan, B.; Feinberg, D.; Hill, A.; McIntosh, R.; Terry, K. Fuels from Microalgae: Technology Status, Potential, and Research Requirements; Pub SER/SP-231-2550; Solar Energy Research Institute: Golden, CO, USA, 1986; pp. 149-158.

19. Sheehan, J.; Dunahay, T.; Benemann, J.; Roessler, P. A Look Back at the U.S. Department of Energy's Aquatic Species Program-Biodiesel from Algae; TP-580-24190, Report NREL/TP; Nation Renewable Energy Laboratory: Golden, CO, USA, 1998; pp. 580-2419.

20. Chung, Y.S.; Lee, J.W.; Chung, C.H. Molecular challenges in microalgae towards cost-effective production of quality biodiesel. Renew. Sustain. Energy Rev. 2017, 74, 139-144. [CrossRef]

21. Smith, V.H.; Sturm, B.S.M.; Billings, S.A. The ecology of algal biodiesel production. Trends Ecol. Evol. 2010, 25, 301-309. [CrossRef] [PubMed]

22. Hernandez, A.C.; Dominguez, P.A.; Cruz, O.A.; Ivanov, R.; Carballo, C.A.; Zepeda, B.R. Laser in agriculture. Int. Agrophys. 2010, 24, 407-422.

23. Yanagisawa, S. Transcription factors involved in controlling the expression of nitrate reductase genes in higher plants. Plant Sci. 2014, 229, 167-171. [CrossRef] [PubMed]

24. Bianucci, E.; Fullana, C.; Furlan, A.; Castro, S. Antioxidant defense system responses and role of nitrate reductase in the redox balance maintenance in Bradyrhizobium japonicum strains exposed to cadmium. Enzym. Microb. Technol. 2013, 53, 345-350. [CrossRef] [PubMed]

25. Kohli, R.; Bose, B.; Gupta, P.K. Induction of phr gene expression in E. coli strain KY706/pPL-1 by He-Ne laser (632.8 nm) irradiation. J. Photochem. Photobiol. B 2001, 60, 136-142. [CrossRef]

26. Lu, W.Y.; Wen, J.P.; Jia, X.Q.; Sun, B.; Chen, Y.; Liu, M.H. Effect of He-Ne laser irradiation on hydrogen production by Enterobacter aerogenes. Int. J. Hydrogen Energy 2008, 33, 34-42. [CrossRef]

27. Ma, F.X.; Chen, X.Y. Laser applications in seed germination, mutation breeding and gene engineering for forestry and horticulture. Phys. Beijing 2007, 36, 637-641.

28. Wang, L.Q.; Yang, G.Z.; Chen, F.D. Biological effects and application in plants and animals heredity and breeding by laser mutation. Acta Laser Biol. Sin. 1996, 6, 1097-1102.

29. Baer, S.; Heining, M.; Schwerna, P.; Buchholz, R.; Hübner, H. Optimization of spectral light quality for growth and product formation in different microalgae using a continuous photobioreactor. Algal Res. 2016, 14, 109-115. [CrossRef]

30. De Mooij, T.; de Vries, G.; Latsos, C.; Wijffels, R.H.; Janssen, M. Impact of light color on photobioreactor productivity. Algal Res. 2016, 15, 32-42. [CrossRef]

31. Wang, M.Z.; Chen, B.L.; Zhuang, H.R.; Ou, L.; Shi, Q.Q.; Wu, S.G. The effect of Nd: YAG laser on Porphyridium cruentum growth and extracellular polysaccharide production. Acta Laser Biol. Sin. 2002, 11, 6-9.

32. Nandakumar, K.; Obika, H.; Shinozaki, T.; Ooie, T.; Utsumi, A.; Yano, T. Pulsed laser irradiation impact on two marine diatoms Skeletonema costatum and Chaetoceros gracilis. Water Res. 2003, 37, 2311-2316. [CrossRef]

33. Katsuda, T.; Lababpour, A.; Shimahara, K.; Katoh, S. Astaxanthin production by Haematococcus pluvialis under illumination with LEDs. Enzym. Microb. Technol. 2004, 35, 81-86. [CrossRef]

34. Kuwahara, S.S.; Cuello, J.L.; Myhre, G.; Pau, S. Growth of the green algae Chlamydomonas reinhardtii under red and blue lasers. Opt. Lasers Eng. 2011, 49, 434-438. [CrossRef]

35. Bodnar, O.I.; Viniarska, H.B.; Vasilenko, O.V.; Grubinko, V.V. Pigment content of Chlorella vulgaris Beij. Under influence of sodium selenite and metals ions. Biotechnol. Acta 2016, 9, 71-78. [CrossRef]

36. Seyfabadi, J.; Ramezanpour, Z.; Khoey, Z.A. Protein, fatty acid, and pigment content of Chlorella vulgaris under different light regimes. J. Appl. Phycol. 2011, 23, 721-726. [CrossRef]

37. Lau, P.S.; Tam, N.F.Y.; Wong, Y.S. Effect of carrageenan immobilization on the physiological activities of Chlorella vulgaris. Bioresour. Technol. 1998, 63, 115-121. [CrossRef]

38. Miao, X.L.; Wu, Q.Y.; Yang, C.Y. Fast pyrolysis of microalgae to produce renewable fuels. J. Anal. Appl. Pyrolysis 2004, 71, 855-863. [CrossRef]

39. Tang, H.Y.; Chen, M.; Garcia, M.E.D.; Abunasser, N.; Ng, K.Y.S.; Salley, S.O. Culture of microalgae Chlorella minutissima for biodiesel feedstock production. Biotechnol. Bioeng. 2011, 108, 2280-2287. [CrossRef] [PubMed]

40. Mehtani, J.; Arora, N.; Patel, A.; Jain, P.; Pruthi, P.A.; Poluri, K.M.; Pruthi, V. Augmented lipid accumulation in ethyl methyl sulphonate mutants of oleaginous microalga for biodiesel production. Bioresour. Technol. 2017, 242, 121-127. [CrossRef] [PubMed] 
41. Kreslavski, V.D.; Fomina, I.R.; Los, D.A.; Carpentier, R.; Kuznetsov, V.V.; Allakhverdiev, S.I. Red and near infra-red signaling: Hypothesis and perspectives. J. Photochem. Photobiol. C Photochem. Rev. 2012, 13, 190-203. [CrossRef]

42. Zhang, C.; Zheng, S.; Meng, F.P. Study on Chlorella pacifica cultivation based municipal sewage sludge. Chin. J. Environ. Eng. 2010, 4, 1186-1190.

43. Guillard, R.R.; Ryther, J.H. Studies of marine planktonic diatoms: I. Cyclotella nana Hustedt, and Detonula confervacea (CLEVE) Gran. Can. J. Microbiol. 1962, 8, 229-239. [CrossRef] [PubMed]

44. Lau, K.Y.; Pleissner, D.; Lin, C.S.K. Recycling of food waste as nutrients in Chlorella vulgaris cultivation. Bioresour. Technol. 2014, 170, 144-151. [CrossRef] [PubMed]

45. Arnon, D.I. Copper enzymes in isolated chloroplasts. Polyphenoloxidase in Beta vulgaris. Plant Physiol. 1949, 24, 1-15. [CrossRef] [PubMed]

46. Arrese-Igor, C.; Garcia-Plazaola, J.I.; Diaz, A.; Apaparico-Tejo, P.M. Distribution of nitrate reductase activity in nodulated lucerne plants. Plant Soil 1991, 131, 107-113. [CrossRef]

47. Jauregui, L.; Aparicio-Tejo, P.M.; Avila, C.; Cañas, R.; Sakalauskiené, S.; Aranjuelo, I. Root-shoot interactions explain the reduction of leaf mineral content in Arabidopsis plants grown under elevated $\left[\mathrm{CO}_{2}\right]$ conditions. Physiol. Plant. 2016, 158, 65-79. [CrossRef] [PubMed]

48. Lim, D.K.Y.; Garg, S.; Timmins, M.; Zhang, E.S.B.; Thomas-Hall, S.R.; Schuhmann, H. Isolation and evaluation of oil-producing microalgae from subtropical coastal and brackish waters. PLoS ONE 2012, 7, e40751. [CrossRef] [PubMed]

49. Bligh, E.; Dyer, W.J. A rapid method of total lipid extraction and purification. Can. J. Biochem. Physiol. 1959, 37, 911-917. [CrossRef] [PubMed]

(C) 2017 by the authors. Licensee MDPI, Basel, Switzerland. This article is an open access article distributed under the terms and conditions of the Creative Commons Attribution (CC BY) license (http:/ / creativecommons.org/licenses/by/4.0/). 